\title{
Civil Society as Peacebuilder in the Internet Era
}

\author{
Edwin Prasetiawan \& Arofatin Maulina Ulfa \\ Jurusan Ilmu Hubungan Internasional, Universitas Jember
}

\begin{abstract}
Peace building in the modern era is different from those in the World War era. While the latter focused more on the state-to-state policy, the former involves the participation of the society. Part of the explanation is the fast growing development of information and technology, particularly the development of internet, which has helped providing more spaces for civil society to involve and to influence peace building process in any humanitarian activities. This space, as manifested in various social media such as Facebook and Twitter, has become a new way for the so-called netizen (internet citizen) to access information on the existing conflicts, advocate or campaign for the management and settlement of the conflicts, gather financial supports for the peace building process, and develop confidence building among people of the conflicting parties. However, at the same time this space may jeopardize the peace building process as people has no restriction in expressing their opinion online which could deteriorate the relations among people from both sides. This paper, therefore, aims to examine the role of this online activism to peace building process in various cases.
\end{abstract}

Keywords: civil society, social media, peace building

\begin{abstract}
Abstrak
Bina damai di era modern berbeda dengan bina damai di era Perang Dunia. Meski bina damai di era Perang Dunia lebih berfokus pada kebijakan negara dengan negara, bina damai di era modern melibatkan partisipasi masyarakat. Salah satu penyebabnya adalah karena berkembangnya informasi dan teknologi secara cepat, terutama berkembangnya internet yang telah membantu memberikan ruang-ruang lebih luas bagi masyarakat sipil untuk terlibat dan mempengaruhi proses bina damai di berbagai aktivitas humaniter. Ruang ini, seperti yang telah termanifestasi dalam berbagai media sosial seperti Facebook dan Twitter, telah menjadi sebuah cara baru bagi netizen (internet citizen atau masyarakat internet) untuk mengakses informasi tentang konflik-konflik yang sedang terjadi, melakukan advokasi atau kampanye untuk manajemen dan penyelesaian konflik, mengumpulkan dukungan finansial untuk mendukung proses bina damai, dan mengembangkan kepercayaan di antara orang-orang yang terlibat dalam konflik. Meski begitu, di saat yang bersamaan ruangan ini bisa juga membahayakan proses bina damai karena orangorang tidak memiliki batasan dalam mengekspresikan opininya di dunia maya yang kemudian dapat membuat hubungan antara pihak-pihak yang terlibat dalam konflik menjadi memburuk. Tulisan ini, oleh karena itu, memiliki tujuan untuk membahas peran aktivisme online ini dalam proses bina damai di berbagai kasus.
\end{abstract}

Kata kunci: masyarakat sipil, media sosial, bina damai 


\section{Pendahuluan}

Permasalahan kemanusiaan menjadi penting dalam hubungan internasional di era globalisasi. Banyaknya peristiwa bencana alam, kerusakan lingkungan, kekerasan, pelanggaran HAM yang terjadi di berbagai belahan dunia membuat orang semakin hirau terhadap permasalahan kemanusiaan. Hal tersebut merupakan bagian dari human security. UNDP menjelaskan pengertian human security adalah menyelamatkan manusia dari ancaman serius dari kelaparan, penyakit ,dan segala tindakan kekerasan serta represi untuk menjamin hak hidup. Gagasan human security dijelaskan dalam laporan UNDP mengenai Human Development Report of the United Nations Development Program pada tahun 1994. Namun gagasan human security mulai menjadi perdebatan setelah perang dingin berakhir. Dalam perspektif Kanada, human security adalah security of the people (keamanan masyarakat) yang berpedoman kepada Piagam PBB, Deklarasi Universal Hak-hak Asasi Manusia serta konvensi Geneva. Dalam hal ini konsep human security berfokus pada human cost yang diakibatkan oleh konflik kekerasan. Amnesty Internasional melaporkan bahwa kasus pelanggaran HAM di Asia Pasifik sangat memprihatinkan. Kasus penggusuran, penyiksaan dan penahanan menjadi sorotan dalam kasus HAM. Negara-negara seperti Kamboja, Vietnam, Korea Utara, Sri Lanka, Pakistan, Myanmar, Thailand, Afghanistan, dan Maladewa ditetapkan sebagai negara yang sebagian masyarakatnya masih mengalami penindasan. Pelanggaran HAM yang terjadi di Palestina, negara-negara Afrika, dan negaranegara dunia lainya juga massif terjadi (Amnesty International.2014).

Pelanggaran-pelanggaran tersebut menyebabkan persoalan kemanusiaan terkonstruksi menjadi suatu hal yang genting sehingga diperlukannya tindakan konkrit dalam memperjuangkan human security. Hal ini memicu peran aktif seluruh aktor dalam hubungan internasional dalam menyelesaikan kasus kemanusiaan. Berbagai kasus pelanggaran HAM yang terjadi di berbagai negara membutuhkan penyelesaian tidak hanya pada level negara. Bahkan negara terkadang tidak mampu menangani permasalahan kemanusiaan yang terjadi dalam domain wilayahnya karena lemahnya otoritas negara dikarenakan norma noninterference yang dianut oleh negara pada umumnya. Hal ini terlihat dalam kasus kekerasan terhadap etnis Rohingya yang justru didukung oleh negara. Oleh karena itu penting melibatkan aktor non-negara dalam menyelesaikan masalah kemanusiaan.

Perkembangan globalisasi yang menuntut relasi dalam sistem internasional tidak hanya terbatas pada aktor negara tetapi juga aktor non negara. Perdamaian dunia akan terwujud jika semua elemen bekerja secara kooperatif dalam menciptakannya. Kerja secara kooperatif dapat diwujudkan melalui keterbukaan arus informasi dan komunikasi. Globalisasi dan perkembangan teknologi semakin mendorong tindakan kooperatif melalui media komunikasi dan informasi berupa internet.

Berkembangnya teknologi internet semakin memudahkan manusia untuk saling terhubung. Interkoneksi yang terjadi semakin luas dan melalui lintas batas wilayah negara. Dampak kecanggihan teknologi menjadikan disparitas wilayah bukan lagi sebagai penghalang bagi proses integrasi baik ditingkat negara maupun masyarakat. Kecanggihan teknologi berdampak pada cara berkomunikasi yang semakin terdigitalisasi. Digitalisasi dalam proses komunikasi juga semakin dipermudah dengan penggunaan gadget (smartphone).

Internet merupakan penemuan mutakhir dalam sejarah peradaban manusia. Fungsi komunikasi dan informasi yang terdapat dalam internet memiliki dampak sosial yang luas (Castells: 2014). Salah satunya adalah pemanfaatanya sebagai alat komunikasi massal. Munculnya platform jejaring sosial seperti Facebook, Twitter, dan Skype, semakin memudahkan manusia diberbagai belahan dunia untuk saling terhubung satu sama lain. Manusia yang memaksimalkan fungsi internet disebut sebagai netizen (internet citizen) atau masyarakat internet. Munculnya netizen di abad modern adalah bentuk sosial cleveages baru (lihat Price. 2013; Goode. 2010). Domain 
mereka berada pada dunia virtual internet. Internet sebagai sebuah lahan tak bertuan tidak memiliki kedaulatan yang mengaturnya. Ruang gerak netizen tidak terikat oleh hukum ataupun norma.

Paper ini berusaha untuk menjelaskan keterlibatan civil society melalui pemanfaatan platform jejaring sosial dan internet sebagai bagian dari upaya bina damai dalam permasalahan kemanusiaan pelanggaran HAM. Paper ini beragumen bahwa intervensi netizen diwujudkan melalui kegiatan aktivisme online dengan memanfaatkan jejaring virtual internet. Melalui gerakan aktivisme online, netizen berusaha berperan sebagai aktor perdamaian dengan mempengaruhi pendapat masyarakat umum bahkan negara di ruang publik maya.

\section{Permasalahan Kemanusian dan HAM dalam Hubungan Internasional}

Permasalahan kemanusiaan menjadi penting dalam studi hubungan internasional. Kekejaman perang dan tindakan pelanggaran HAM menjadi trauma sejarah yang terus menjadi hantu hingga sekarang. Studi perdamaian kemudian menjadi relevan dalam berbagai kasus pelangaran HAM. Declaration of Human Rights, misalnya, muncul sebagai teks perdamaian yang menjadi landasan disepakatinya nilai-nilai universal tentang kemanusiaan. Deklarasi ini memuat pasal yang menyatakan semua umat manusia dilahirkan merdeka dan sederajad dalam martabat dan hak-hak asasi.

Beberapa perjanjian internasional tersebut menandai bahwa humanitarianisme dan perdamaian dalam hubungan internasional masih menjadi hal yang kerap diperdebatkan. (Richmond, 2008). Perdamaian dalam hubungan internasional dimaknai sebagai perdebatan nyata dan memerlukan jawaban nyata. Perdebatan ini memerlukan pandangan yang menyeluruh. Karena ketika perdebatan ini dibuka, banyak perspektif yang muncul baik itu dalam pengertian liberal, illiberal, radikal, maupun subversif. Ada kegamangan dalam definisi perdamaian karena terjadinya dua perang dunia dan perang dingin tidak bisa menciptakan perdamaian yang dimaksud oleh perspektif liberal. Yang terjadi adalah victor peace yaitu bahwa akan ada pihak yang menang dan yang kalah. Institusionalisasi perdamaian menyediakan aturan internasional dan jaminan melalui demokrasi dan pasar bebas, serta perdamaian sipil untuk memastikan kebebasan dan HAM dalam masyarakat. Hal tersebut merupakan pengertian perdamaian dalam versi AngloAmerika yang menempatkan individu sebelum negara. Di lain pihak, variasi kontinental Eropa melihat bahwa individu adalah subordinat dari negara. Kedua variasi tersebut terletak pada kontrak sosial antara masyarakat dan elit. Sejak 1989, terdapat indikasi bahwa perdamaian yang terjadi tidak seperti yang dijelaskan sebelumnya. Konsensus cara pandang terhadap perdamaian ala liberal peace ketika menyangkut hal yang berbau teknis, politis, sosial, ekonomi, intelektual, pasca Perang Dingin masih diperdebatkan lagi definisi serta metode yang digunakan.

Seringkali negara juga melakukan pelanggaran HAM karena cenderung memiliki tabiat menindas. Sebagai otoritas yang berwenang dalam menciptakan perdamaian, Negara seharusnya betindak sebagai pihak yang melakukan intervensi dalam upaya menciptakan perdamaian. Meskipun tidak semua tindakan pelanggaran HAM dilakukan oleh negara, mengandalkan peran negara dalam penegakan HAM dan perdamaian memunculkan skeptisisme. Catatan sejarah menunjukkan kekejaman perang dan kekerasan terhadap manusia justru dipicu oleh agresivitas negara. Misalnya yang terjadi pada Perang Dunia dan beberapa konflik perebutan hegemoni pada masa Perang Dingin. Dominasi aktor negara dalam penciptaan perdamaian justru lebih menonjolkan sifat struggle for power yang berakibat pada definisi perdamaian hanya terikat pada victor peace atau perdamaian yang sifatnya zero sum game. Oleh karena itu, diperlukan aktor non-negara dalam mencapai konsensus perdamaian. Pentingnya aktor non negara dalam mewujudkan perdamaian adalah sebagai watchdog sekaligus kekuatan penyeimbang (balancing force) dari 
kecenderungan intervensionis negara (Cohen dalam Hikam dalam Triwibiwo, 2006).

Peran aktor non-negara dapat dimaksimalkan melalui adanya civil society sebagai entitas dalam sistem sosial. Disamping itu, selama ini tindakan transformatif terjadi karena keterbukaan arus informasi dari internet. Melalui internet, kita mampu saling berhubungan, bertukar informasi, dan juga membangun apa yang disebut sebagai solidaritas dunia maya. The network society, seperti yang pernah diungkapkan oleh Manuel Castelle, membuka peluang bagi terciptanya jaringan aktivis global dibidang HAM. Dengan begitu, para aktivis mampu berkomunikasi dan berkoordinasi untuk memperjuangkan isu tertentu, termasuk kemanusiaan. Mengkonstruksi perdamaian melalui peran civil society dan memaksimalkan peran media massa menjadi relevan dalam upaya bina damai. Pada akhirnya, perdamaian dapat dipahami sebagai norma universal yang harus diperjuangkan.

\section{Peran Civil Society}

Konsep masyarakat sipil atau civil society merupakan konsep yang terus diperdebatkan definisinya. Konsep ini memenuhi perdebatan-perdebatan kontemporer mengenai ilmu ekonomi, politik, dan sosial. Menurut Collins English Dictionary, civil society merupakan elemen-elemen seperti kebebasan berbicara dan pengadilan independen yang menyusun sebuah masyarakat demokratis (Collins English Dictionary, 2015) atau dalam pernyataan Ernest Gellner, tanpa civil society, tidak ada demokrasi (Gellner, 1994). Sementara menurut WHO, civil society dilihat sebagai sebuah lapisan sosial yang terpisah dari negara dan pasar (WHO, 2015). BBC (2001) dalam liputan khususnya mengenai civil society, mendefinisikan konsep ini sebagai ruangan publik yang berada diantara negara, pasar, dan rumah tangga pada umumnya. Di dalam ruangan ini, orang dapat melakukan debat tentang suatu isu dan mengambil aksi terhadap isu tersebut. Berdasarkan definisi ini, yang dapat disebut sebagai civil society memiliki spektrum yang sangat luas seperti yayasan amal, skema saling bantu antartetangga, badan-badan internasional seperti PBB dan Palang Merah Internasional, kelompok-kelompok penekan berbasis religi, kampanye HAM di masyarakat represif, LSM yang berkecimpung di bidang kesehatan, pendidikan, dan standar hidup baik di negara berkembang maupun negara maju (BBC World Service, 2001).

Perkembangan konsep yang semakin meluas ini merupakan akibat dari ketidakmampuan disiplin-disiplin ilmu ini untuk memberikan penjelasan yang memadahi terhadap perkembangannya. Pengadopsian terhadap sistem politik demokrasi oleh negara-negara modern menjadi sistem pemerintahannya, membuat semakin menguatnya peran-peran masyarakat sipil dalam pengambilan keputusan. Masyarakat sipil yang sebelumnya digambarkan sebagai pihak yang pasif dalam sistem politik kini menjadi aktif dalam menyoroti isu-isu publik.

Menguatnya peran civil society dalam sistem politik yang ada merupakan hasil dari proses yang tidak pendek. Masyarakat sipil muncul dari pemikiran filsuf-filsuf Inggris yang menitikberatkan pada adanya kontrak sosial. ${ }^{1}$ Thomas Hobbes menitikberatkan pada kuatnya peran negara sebagai satusatunya penjaga perdamaian serta pencegah kondisi bellum omnium contra omnes (semua lawan semua). Karena ketika kondisi semua lawan semua ini terjadi maka hak-hak individu tidak terjamin keberlangsungannya, Dilain pihak, John Locke menitikberatkan pada adanya kebebasan individu untuk kehidupan sosialnya dan secara tidak langsung akan menjamin keberlangsungan masyarakat sipil. Individu-individu memberikan sedikit kebebasannya berupa mandat kepada negara untuk menjamin kebebasan individu. Kebebasan individu yang didengungkan oleh John Locke menjadi populer saat ini karena peran negara yang minimal seperti dianjurkan oleh teoritis

${ }^{1}$ kontrak sosial merupakan kesepakatan diantara masyarakat sipil untuk membentuk peraturan yang mengikat dengan memberikan mandat pada negara untuk menegakkan peraturan tersebut. 
liberal menjadi dominan dan dianut oleh negara-negara modern (Pietrzyk. 2001).

Alexis de Tocqueville (1863) menyebut civil society sebagai asosiasi sipil. Civil association ini menarik perhatian karena kesuksesannya membangun sistem demokrasi. Akan tetapi, pemerintah demokratis tidak serta merta menjamin kebebasan warganya. Tocqueville melihat hal ini sebagai kecenderungan negara untuk menjadi despotisme, yaitu ketika sistem demokrasi di dalamnya tidak diisi oleh orangorang yang berasal dari masyarakat demokratis. Untuk menjamin hak-hak individu, De Tocqueville (1863) melihat civil society sebagai bentuk asosiasi politik dimana ia bergerak untuk mempromosikan hal-hal publik untuk menjadi perhatian bersama.

Aktifnya masyarakat sipil dalam mengawal kebijakan yang dihasilkan pemerintah secara efektif dijalankan dalam bentuk organisasi-organisasi masyarakat sipil. Organisasi masyarakat sipil yang memiliki struktur ini menjadi kelompok-kelompok kepentingan yang terfragmentasi berdasarkan isu-isu publik (Imawan, 2013). Luasnya fragmentasi terhadap isu-isu yang berkembang ini berakibat pada tingginya jumlah organisasi masyarakat sipil. Heterogenitas ini menjadi kekuatan penyeimbang dari dominasi negara dan pasar serta menjadi kekuatan ketiga dalam struktur politik modern (Keane. 2003: 65). Selain jumlah yang sangat banyak kekuatan dari organisasi masyarakat sipil terdapat pada dua hal yaitu sebagai Agen advokasi terhadap masyarakat dikarenakan kemampuannya untuk menjangkau masyarakat terpencil dan sebagai pemotongan jalur yang dilalui pemerintah dalam penerapan kebijakan (Riker dalam Widjajanto. 2007: 38).

Perkembangan masyarakat yang tidak lagi dalam lingkup skala nasional melainkan juga internasional telah mengembangkan isuisu yang sebelumnya sebagai masalah nasional kemudian menjadi perhatian internasional. Konsekuensinya, jumlah organisasi masyarakat sipil pun terus meningkat hingga lebih dari 50.000 organisasi pada tahun 2003 saja dan isu yang ditangani pun semakin luas.
Meskipun demikian, munculnya organisasi masyarakat sipil sebagai aktor dalam sistem internasional tidak serta merta menggantikan dominasi negara (Tvedt.2002). Akan tetapi lebih kepada mengisi jenjang yang tidak bisa di penuhi negara seperti yang disebutkan Riker. Bahkan keberadaan gerakan masyarakat sipil lintas negara atau yang biasa disebut transnasionalisme masyarakat sipil atau masyarakat sipil global pun tidak dapat dikatakan sebagai pesaing negara. Operasi yang dijalankan tetap harus masuk ke dalam jurisdiksi batas wilayah negara. Namun hal ini pula lah yang kemudian sering dikritik sebagai keterbatasan gerakan dan organisasi masyarakat sipil.

\section{Internet dan Operasi Bina Damai}

Proses bina damai adalah proses yang rumit (Cubitt. 2013) mengingat luasnya ruang lingkup studi perdamaian. Namun dalam bab ini, penulis berusaha memfokuskan studi perdamaian dan proses bina damai dalam kerangka gerakan aktivisme online. Asumsi yang dibangun adalah civil society merupakan aktor yang mengkampanyekan isu-isu perdamaian dan HAM. Civil society memanfaatkan platform internet dan media sosial sebagai instrumen untuk mempengaruhi pendapat masyarakat tentang suatu konflik.

Media sosial adalah media online yang dinamis yang telah mengubah cara kita bekerja. Mirip dengan media tradisional, media sosial menawarkan kesempatan untuk mengumpulkan dan berbagi berita, berkomunikasi dan melakukan advokasi untuk perubahan. Namun, tidak seperti media tradisional, media sosial memungkinkan interaksi untuk hal ini terjadi pada website secara real-time melalui jaringan sosial global atau regional. Beberapa platform media sosial yang populer adalah Facebook, YouTube, Twitter, Google+, LinkedIn, Instagram dan Pinterest. Namun, platform baru muncul setiap hari dan penting untuk mengikuti perkembangan ini untuk menilai keberhasilan media sosial. Data yang dirilis statista menunjukan sekitar 1,79 milyar manusia di dunia menggunakan situs jejaring sosial pada 
periode 2010 hingga 2014 (Statista.com, 2015).

Aktivisme Internet adalah bentuk aktivisme yang dilakukan di dunia maya. Aktivisme merupakan kegiatan yang menjadi bagian dari gerakan sosial. Gerakan aktivisme adalah upaya tercapainya perubahan sosial. Perubahan tersebut umunya ditujukan kepada para pembuat kebijakan, atau sekedar untuk mempengaruhi pemikiran masyarakat luas. Tim Jordan menjelaskan bahwa :

\section{Activism is essentially something done together by many people, but we must be careful with the sense of group or collective that is employed here. What is essential to activismis not simply being more than one, as we are in a cinema, but a sense of solidarity in pursuit of transgression. There has to be a sense of shared identity, which can best be understood at this stage as people recognizing in one another the anger, fear, hope or other emotions they feel about a transgression. (Jordan, 2002)}

Gerakan masyarakat sipil global bergerak berdasarkan aktivisme yang dibangun dalam skala global. Aktivisme yang berdasarkan masyarakat sipil tentu tidak memiliki kekuatan seperti yang dimiliki oleh negara. Organisasi masyarakat sipil yang diidentikkan dengan organisasi non pemerintah menyebarkan ide-ide perdamaian dengan penguatan masyarakat sipil di dalam negara yang berkonflik. Hal ini dilakukan untuk mendorong kelompok masyarakat sipil di dalam negara tersebut untuk menyebarkan ide-ide perdamaian di internal negara (lihat Anheier, et al eds. 2007: 94). Secara konvensional, lembaga-lembaga donor ini memberikan kemampuan masyarakat sipil lokal untuk memiliki otonomi dalam kegiatankegiatannya tanpa tergantung dari pemerintah. Hal inilah yang membuat peran mereka diperhitungkan dalam kegiatan penciptaan perdamaian di negara berkonflik. Terlebih negara tidak mampu memberikan jaminan terhadap stabilitas internal.
Tongeren (2013) menyoroti adanya gerakan bottom up oleh masyarakat sipil yang membentuk kepanitiaan lokal yang terdiri dari para tetua adat untuk mewujudkan perdamaian dalam skala yang kecil pada daerah yang berkonflik. Kepanitiaan lokal yang terdiri dari masyarakat ini merupakan perwujudan dari penciptaan perdamaian di level tingkat kota di berbagai negara konflik seperti Afghanistan, Kongo, Kolombia. Kepanitiaan ini sangat bermanfaat untuk mengendalikan konflik horizontal yang lebih menekankan pada konflik berdasarkan etnisitas. Kelebihan lain adalah panitia perdamaian ini lebih cair dalam penciptaan perdamaian karena kemampuannya untuk mempertemukan pemimpin-pemimpin konflik sehingga berpengaruh terhadap pengikut kelompok masing-masing.

Aktivisme online menekankan pada mekanisme kampanye melalui internet. Aktivisme online dapat memanfaatkan media sosial sebagai media kampanye dalam menyoroti isu kemanusiaan dan HAM. Salah satu situs misalnya menyoroti kampanye bina damai melalui monitoring terhadap isu tertentu. Di Kenya, Ushahidi merupakan situs yang mengembangkan monitoring terhadap kericuhan yang terjadi akibat pasca pemilihan umum 2007 (Okolloh. 2008). Ushahidi bergerak melalui adanya monitoring berbasis crowdsourcing. Ushahidi bertujuan untuk memberikan informasi mengenai kericuhan berdasarkan laporan sukarelawan yang terkirim pada server Ushahidi. Dari laporan tersebut diolah menjadi peta untuk memberikan informasi dimana letak kerusuhan dan para pengguna dapat menggunakan informasi tersebut untuk menghindari lokasi yang ditandai di dalam peta. Informasi yang didapat secara real time membantu organisasi masyarakat sipil baik lokal maupun internasional di dalam situasi krisis.

Ushahidi berkembang tidak hanya terbatas pada pencegahan konflik. Penggunaan sebagai pelaporan terhadap krisis humanitarian berupa bencana alam, penyebaran penyakit, pengawasan terhadap konflik pasca pemilu, serta serangan terorisme. Pengunaan Ushahidi yang didesain 
untuk memberikan penguatan hingga level komunitas lokal. Informasi yang dikirim server mampu memotong jalur komunikasi tradisional. Sehingga data informasi yang didapatkan oleh pengguna dapat secara langsung digunakan. Sistem maping berguna untuk menandai lokasi-lokasi yang rentan terhadap timbulnya masalah dan melihat tren yang ada di lapangan.

Selain Ushahidi terdapat situs petisi online yang menjadi salah satu platform kampanye online. Situs petisi online menyoroti berbagai permasalahanpermasalahan kemanusiaan. Salah satunya adalah change.org. Petisi online terfokus pada tekanan yang mampu diciptakan oleh netizen terhadap pihak tergugat. Salah satu contoh kasus colective rape di Afrika Selatan. Masyarakat Afrika Selatan memiliki tradisi pemerkosaan yang legal terhadap perempuan yang dianggap tidak normal, seperti lesbian. Menurut mereka, cara untuk membuat perempuan tersebut kembali normal adalah dengan memperkosanya. Tradisi ini sudah berlangsung lama di Afrika Selatan, sampai suatu ketika seorang perempuan tidak menerima praktek ini terus berlangsung. Dia memulai petisi online, dan banyak mendapatkan solidaritas dari berbagai negara agar collective rape ini segera dihapuskan di Afrika Selatan. Akhirnya tradisi ini pun dihapuskan. Adanya internet mendorong peran partisipasi masyarakat dan netizen untuk menyoroti masalah-masalah publik (Thornton. 2001). Salah satunya dalam penyelesaian konflik. Peran aktif masyarakat sipil menjadi salah satu alternatif penyelesaian kasus HAM di dunia. Netizen sebagai bagian dari civil society mampu berperan sebagai pelaku intervensi melalui upaya bina damai dalam kasus pelanggaran HAM.

Tapi disisi lain, ketiadaan fisik aktivisme online menjadi hambatan terhadap kinerja netizen dalam mewujudkan perdamaian. Tingkat efektivitasnya belum maksimal. Hal ini di dasarkan pada ruang lingkup kerja aktivisme online yang masih di anggap maya dan utopis. Dalam hal pengaruhnya terhadap kebijakan pemerintah, akan berbenturan dengan kinerja sistemik dalam pemerintahan dikarenakan masih adanya prosedur-prosedur yang harus dilalui dalam menciptakan pengaruh bagi pengambilan kebijakan. Dengan munculnya internet, negara juga tidak mau kalah dalam melakukan penetrasinya ke dalam ranah dunia maya ini (De Nardis. 2012; Yang.2014). Pada akhirnya, legitimasi dari berbagai aktivisme online ini masih diperdebatkan.

Pendekatan-pendekatan liberal yang merupakan arus utama dalam kajian mengenai masyarakat sipil dan perdamaian yang melihat bahwa negara harus seminimal mungkin dalam kehidupan negara menjadi kurang relevan. Hal tersebut terjadi pada negara-negara yang sedang terjadi konflik. Negara yang tidak cukup mampu membawa stabilitas internal dan berakibat pada pelemahan terhadap peran masyarakat sipil. Kondisi tersebut berbeda dengan masyarakat di negara-negara yang sudah mapan baik dalam menjalankan demokrasi dan kebebasan dalam mendapatkan internet. Sebagai pihak yang hanya menyoroti kinerja pemerintah serta mendorong pemerintah untuk melakukan aksi tertentu dalam pelaksanaan perwujudan perdamaian netizen tidak bisa melakukan lebih dari pada penyebaran isu. Strategi "boomerang" yang digadang gadang sebagai strategi untuk melakukan pemberian sangsi sosial terhadap negara juga tidak bisa mendorong negara untuk melakukan lebih dari apa yang diinginkan oleh kelompok masyarakat sipil ini ${ }^{2}$ Implikasinya, mengkonstruksi perdamaian melalui jejaring aktivisme online hanya dapat menyasar pada negara-negara yang sudah mapan dalam sistem demokrasi.

Pada akhirnya, teknologi memang bukan sebagai panacea akan tetapi penggunaan teknologi mampu memangkas

${ }^{2}$ Strategi boomerang ini merupakan konsep yang diajukan Margareth Keck dan Kathryn Sikkink.Strategi ini merupakan langkah yang dijalankan oleh organisasi masyarakat sipil yang berkecimpung pada isu-isu internasional.Dengan jalan memberikan "resonansi" terhadap aktivis dalam negara ketika menyoroti perilaku negara yang dianggap melanggar isu-isu ataupun perjanjian yang telah diratifikasi semisal HAM.

Lihat Margareth Keck dan Kathryn Sikkink

Transnasional Advocacy Networks In International And Regional Politics dalam

http://courses.washington.edu/pbaf531/KeckSikkink.pdf 
jalur birokrasi tradisional. Sehingga informasi yang disajikan secara real time mampu dimanfaatkan setiap anggota masyarakat yang mengakses terhadap informasi tersebut. Hal ini juga tidak terlepas dari kemampuan teknologi untuk melihat tren di lapangan sehingga pencegahan dapat dilakukan secara segera. Termasuk dalam hal menegakkan HAM dan pencegahan konflik.

\section{Daftar Pustaka}

\section{Buku}

Anheier, H., Glasius, M. and Kaldor, M. (eds) (2001). Global civil society 2001. Oxford: Oxford University Press.

Gellner, E. (1994). Conditions of Liberty: Civil Society and Its Rivals. London: Hamish Hamilton.

Jordan . T., 2002, Activis $\mid m$ : Direct Action, Hactivism and the Future of Society. London : Reaktion Books.

Kaldor, M., Kostovicova, D \& Said, Y. (2007) War and Peace: The Role of Global Civil Society dalam Anheier, H., kaldor, M. and Glasius, M. (2007) .Global Civil Society 2006/o7. London: Sage.

Keane, J. (2003). Global civil society?. Cambridge: Cambridge University Press.

Richmond, Oliver P. (2008) Peace in International Relations. New York: Routledge.

Schmidt, E. \& Cohen, J. Hanna, Selviya (pent.) (2014) The New Digital Age. Jakarta: Gramedia.

Vegh. S. (2003) Classifying Forms of Online Activism: The Case of Cyberprotests against the World Bankdalam McCaughey, M. and Ayers, M. (eds) (2003) Cyberactivism. New York: Routledge.

Widjajanto, A. (2007). Transnasionalisasi masyarakat sipil. Depok: FISIP UI Press.

Triwibowo, D. (2006). Gerakan Sosial : Wahana Civil Society Bagi Demokratisasi. Jakarta : LP3ES.

\section{Jurnal}

Blank, G. \& Groselj, D. (2014) Dimensions of Internet use: amount, variety, and types, Information, Communication \& Society, $\quad 17: 4, \quad 417-435$, DOI:10.1080/1369118X.2014.889189.

Cubitt, C. (2013) Constructing civil society: an intervention for building peace. Peace building1:1, 91-108.

DeNardis, L. (2012) Hidden Levers Of Internet Control, Information, Communication \& Society, 15:5, 720-738, DOI: 10.1080/1369118X.2012. 659199 .

Eaton, M. (2010) Manufacturing Community In An OnlineActivist Organization, Information, Communication \& Society, 13:2, 174-192, DOI:10.1080/ 13691180902890125 .

Goode, L. (2010) Cultural Citizenship Online: The Internet and Digital Culture. Citizenship Studies 14:5 527-542.

Harlow, S. \& Harp, D. (2012) Collective Action On The Web, Information, Communication \& Society, 15:2, 196216, $\quad$ DOI: 10.1080/1369118X.2011.591411.

Imawan, R.P. (2013) Dua Aktor Demokrasi: Menelisik Peran Organisasi Masyarakat Sipil di Indonesia. Prisma. 32:4, 28-37.

Kittilson, M.C. \& Dalton, R.J. (2011) Virtual Civil Society: The New Frontier of Social Capital? Polit Behav 33, 625644.

Marchetti, R. \& Tocci, N. (2009) Conflict Society: Understanding The Role of Civil Society in Conflict, Global Change, Peace \& Security. 21:2. 201217.

Price, E. (2013) Social Media and Democracy Australian Journal of Political Science, 48:4,519-527.

Sommerfeldt, E.J. (2013) Online Power Resource Management: Activist Resource Mobilization, Communication Strategy, and Organizational Structure, Journal of Public Relations Research, 25:4, 347-367, DOI: 10.1080/1062726X. 2013.806871. 
Suharko (2003) NGO, Civil Societydan Demokrasi: Kritik Atas Pandangan Liberal. Jurnal Ilmu Sosial dan Ilmu Politik, 7: 2, 205-226.

Thornton, A.L. (2001) Does the internet create democracy?, Ecquid Novi: African Journalism Studies, 22:2, 126-14.

Tvedt, T. (2002) Development NGOs: Actors in a Global Civil Society or in a New International Social System? Voluntas: International Journal of Voluntary and Nonprofit Organizations, Vol. 13, No. 4, Global Civil Society (December 2002), pp. 363-375.

van Leeuwen, M. \& Verkoren, W. (2012) Complexities and Challenges for Civil Society Building in Post-Conflict Settings, Journal of Peace building \& Development, 7:1, 81-94, DOI: 10.1080/15423166.2012.719353.

van Tongeren, P. (2013) Potential Cornerstone of Infrastructures For Peace? How Local Peace Committees Can Make a Difference, Peace building, $\quad 1: 1, \quad 39-60$, DOI:10.1080/21647259.2013.756264.

Verkoren, W. \& van Leeuwen, M. (2013) Civil Society in Peace building: Global Discourse, Local Reality, International Peacekeeping, 20:2, 159-172, DOI: 10.1080/13533312.2013.791560.

Yang, G. (2014) The Return of Ideology and the Future of Chinese Internet Policy, Critical Studies in Media Communication, 31:2, 109-113, DOI: 10.1080/15295036.2014.913803.

\section{Artikel dalam Jaringan}

http://www.change.org/id

http://www.statista.com

Amnesty International. 2014. Amnesy International Report 2014/2015. Asia Pasific Regional Overview dalam https://www.amnesty.org/en/countri es/asia-and-the-pacific/report-asiapacific/ diakses tanggal 16 September 2014

BBC World Service (2001) What is Civil Society? dalam http://www.bbc.co.uk/worldservice/p eople/highlights/010705_civil.shtml diakses tanggal 25 Juni 2015.

Castells, M. (2014) The Impact of The Internet on Society: A Global Perspective dalam

http://www.technologyreview.com/vi ew/530566/the-impact-of-the-

internet-on-society-a-global-

perspective/ diakses tanggal 24 Juni 2015.

Collins English Dictionary. (2015). Civil Society dalam http://www.collinsdictionary.com/dic tionary/english/civil-society diakses tanggal 25 Juni 2015.

de Tocqueville, A. (1863) Chapter 12: Political Association In The United States. Dalam http://xroads.virginia.edu/ $\sim$ HYPER/DETOC/1_ch12.htm diakses tanggal 16 September 2014.

Keck, M. \& Sikkink, K. (1999) Transnasional Advocacy Networks In International And Regional Politics dalam http://courses.washington.edu/pbaf5 31/KeckSikkink.pdf diakses tanggal 10 Oktober 2014.

Okolloh,O. (2008). Ushahidi, or 'testimony': Web 2.0 tools for crowdsourcing crisis information dalam http://pubs.iied.org/pdfs/G02842.pd f diakses tanggal 24 Juni 2015.

Pietrzyk, D.I. (2001) Civil Society: Conceptual History from Hobbes to Marx Marie Curie Working Papers -No 1 diakses dari http://graduateinsti tute.ch/files/live/sites/iheid/files/site s/political_science/shared/political _science/1836/Week_3_Petrzyk.pdf pada tanggal 16 September 2014.

The Internet Big Picture World Internet Users and Population Stats 2014 http://www.internetworldstats.com/s tats.htm diakses tanggal 10 Oktober 2014.

WHO. (2015). Civil Society dalam http://www.who.int/trade/glossary/s toryoo6/en/ diakses tanggal 24 Juni 2015. 
